\title{
PUBLICZNY OBROŃCA PRAW REPUBLIKI CZESKIEJ JAKO ORGAN DO SPRAW RÓWNOŚCI W KONTEKŚCIE STANDARDÓW WYZNACZANYCH PRZEZ DYREKTYWY UNII EUROPEJSKIEJ
}

\begin{abstract}
Streszczenie. Przedmiotem niniejszego opracowania jest ocena działalności Publicznego Obrońcy Praw Republiki Czeskiej w zakresie wykonywania działań powierzonych mu od 2009 roku jako krajowemu organowi do spraw równości. Ma on przyczyniać się do promowania prawa do równego traktowania wszystkich osób bez względu na ich rasę, pochodzenie etniczne, narodowość, płeć, orientację seksualną, wiek, niepełnosprawność, religię, przekonania czy poglądy. W tym zakresie działa według postanowień Konstytucji Republiki Czeskiej, Karty Podstawowych Praw i Wolności, tzw. ustawy antydyskryminacyjnej oraz wielu innych ustaw. Zadania te zostały ombudsmanowi powierzone w ramach stosowania dyrektyw Unii Europejskiej. Podkreślano w nich, że jednym ze sposobów wzmocnienia ochrony przed dyskryminacją w państwach członkowskich UE jest powołanie organów, których zadaniem byłoby analizowanie problemów związanych z dyskryminacją, badanie możliwych rozwiązań i świadczenie konkretnej pomocy ofiarom. Autorka niniejszego opracowania zastanawia się, czy Publiczny Obrońca Praw spełnia wymogi stawiane krajowym organom do spraw równości, powołując się na kryteria określone w tzw. zasadach paryskich, które w sposób szczegółowy określają aspekt niezależności funkcjonowania instytucji stojących na straży praw człowieka. Ponadto przedstawia podstawowe założenia, na których opiera się działalność czeskiego ombudsmana oraz informacje dotyczące praktyki jego działalności w obszarze zapewnienia realizacji zasady równości.

Słowa kluczowe: Publiczny Obrońca Praw Republiki Czeskiej, krajowy organ do spraw równości, Konstytucja Republiki Czeskiej, Karta Podstawowych Praw i Wolności, zasada równości, zakaz dyskryminacji.
\end{abstract}

1.

Konstytucja Republiki Czeskiej z dnia 16 grudnia 1992 roku nie zawiera katalogu praw i wolności jednostki, jednak wśród uregulowanych w jej treści zasad podstawowych, w art. 3 uznała Kartę Podstawowych Praw i Wolności ${ }^{1}$ jako część porządku konstytucyjnego Republiki Czeskiej. Oznacza to, że postanowieniom Karty nadaje się rangę norm konstytucyjnych (Kruk 2009, 18; Skotnicki 2000, 20).

${ }^{*}$ Uniwersytet Gdański, Wydział Prawa i Administracji, Katedra Prawa Konstytucyjnego i Instytucji Politycznych, agnieszka.gajda@ug.edu.pl.

${ }^{1}$ Karta Podstawowych Praw i Wolności (zwana dalej Kartą), Ustawa konstytucyjna nr 1/1993 Sb. W języku polskim: http://libr.sejm.gov.pl [dostęp 23.01.2018]. 
Ponadto w treści Konstytucji wskazano wartości, na których opiera się system podstawowych praw i wolności. Już w preambule znajduje się odwołanie do niepodważalnych wartości ludzkiej godności i wolności. Mowa jest również o równouprawnionych, wolnych obywatelach, świadomych swych obowiązków wobec innych i odpowiedzialności wobec ogółu, a także o poszanowaniu praw człowieka, na których oparte jest wolne i demokratyczne państwo - Republika Czeska. W rozdziale pierwszym, poświęconym zasadom podstawowym, w art. 1 Konstytucji znalazło się stwierdzenie, że Republika Czeska jest suwerennym, jednolitym i demokratycznym państwem prawa, opartym na poszanowaniu praw i wolności człowieka i obywatela, a w art. 4 zawarta została zasada sądowej ochrony podstawowych praw i wolności.

Karta Podstawowych Praw i Wolności powstała jeszcze za czasów Czechosłowacji i miała „dokumentować zachodzące w tamtym państwie zmiany ustrojowe" (Skotnicki 2009, 658). Jej treść wzorowana była na Powszechnej Deklaracji Praw Człowieka z 1948 roku oraz konwencjach międzynarodowych, takich jak Konwencja o Ochronie Praw Człowieka i Podstawowych Wolności z 1950 roku, Międzynarodowe Pakty Praw Człowieka ONZ z 1966 roku. W związku z tym, w Karcie odnaleźć można nawiązanie do prawa naturalnego i uznanie niewzruszalności przyrodzonych praw człowieka. Postawienia w niej zawarte odpowiadają współczesnym standardom wyznaczanym na szczeblu międzynarodowym z zakresu ochrony praw człowieka. Karta w pierwszym rozdziale statuuje zasadę, zgodnie z którą ludzie są wolni i równi w swej godności i w prawach. Na podstawie jej art. 1. podstawowe prawa i wolności są nieodstępowalne, niezbywalne, nieprzedawnialne i nienaruszalne. Republika Czeska oparta jest zaś na wartościach demokratycznych i nie może być skrępowana ani wyłączną ideologią, ani wyznaniem religijnym. W Karcie nie znajdujemy katalogu obowiązków obywatelskich, co jest rozwiązaniem charakterystycznym w państwach postsocjalistycznych, w których konstytucjach skupiano się raczej na prawach i wolnościach ${ }^{2}$. Jak podkreśla K. Skotnicki, brak przepisu umożliwiającego bezpośrednie stosowanie postanowień Karty jest niewątpliwie jej wadą (Skotnicki 2009, 659). Stąd w jej treści musiały znaleźć się liczne przepisy odsyłające, przy czym dodatkowe trudności interpretacyjne powoduje fakt, że ustawy będące źródłem odesłań często pochodzą z różnych okresów funkcjonowania państwa. Niewątpliwie jednak Karta Podstawowych Praw i Wolności przyczyniła się do ukształtowania nowego, respektującego prawa człowieka ustroju Republiki Czeskiej.

Zgodnie z treścią Karty podstawowe prawa i wolności są gwarantowane każdemu, bez względu na płeć, rasę, kolor skóry, język, wiarę i religię, poglądy polityczne i inne, pochodzenie narodowe i społeczne, przynależność do mniejszości

${ }^{2} \mathrm{~W}$ artykule 4 Karty wprowadzono zasadę, zgodnie z którą nakładanie obowiązków na jednostkę możliwe jest tylko w drodze aktu o randze ustawy, przy uwzględnieniu przysługujących jej praw i wolności. 
narodowej lub etnicznej, majątek, urodzenie lub pozycję (art. 3 ust. 1). Co więcej, zgodnie $\mathrm{z}$ art. 3 ust. 3 Karty niedopuszczalne jest pozbawienie jednostek prawa do korzystania z ich podstawowych praw i wolności. Dopuszczalne są jednak ich ograniczenia na zasadach określonych w samej Karcie, a więc tylko na podstawie ustawy, i muszą być wprowadzane jednakowo w tego samego rodzaju sytuacjach (art. 4 ust. 3). Ponadto nie mogą naruszać istoty i charakteru praw i wolności (art. 4 ust. 4) i nie mogą być wykorzystywane dla osiągnięcia innych niż określone w Karcie celów (art. 4 ust. 4 in fine). Ponieważ Czechosłowacja była państwem wielonarodowym, podobnie zresztą jak obecnie Republika Czeska, szczególną uwagę w Karcie poświęcono postanowieniom dotyczącym mniejszości narodowych, umieszczając je w osobnym, trzecim rozdziale. Tam też znajduje się dodatkowo zakaz dyskryminacji ze względu na przynależność do jakiejkolwiek mniejszości narodowościowej lub etnicznej (art. 24) .

W Karcie zawarto obszerny katalog praw i wolności człowieka i obywatela, jak również ich gwarancji o charakterze materialnym i formalnym. Jednak ani w Konstytucji z 1992 roku, ani w Karcie Podstawowych Praw i Wolności nie znalazły się przepisy odnoszące się do instytucji ombudsmana, który w Republice Czeskiej nie ma statusu organu konstytucyjnego.

2.

W Republice Czeskiej instytucja ombudsmana nie ma długiej tradycji. Nawet po 1990 roku nie od razu zdecydowano się na jej utworzenie. Nie skłoniły do tego nawet takie fakty historyczne jak upadek reżimu komunistycznego, który z założenia utrudniał tworzenie instytucji stojących na straży praw jednostki, rozpad Czechosłowacji, uchwalenie Konstytucji Republiki Czeskiej w 1992 roku, a nawet ratyfikowanie przez ten kraj traktatów międzynarodowych z zakresu ochrony praw człowieka. Nad ustawą pracowano w atmosferze burzliwych dyskusji, w których wielokrotnie wyrażano wątpliwości, a nawet podważano potrzebę powołania instytucji ombudsmana (Skotnicki 2009, 659-660). Zmianę nastawienia spowodowały m.in. starania Rady Europy, która już w 1985 roku zaleciła rozważenie możliwości powołania ombudsmana na szczeblu krajowym, regionalnym lub lokalnym, lub dla określonych obszarów administracji publicznej oraz nadanie takiemu organowi szczególnych uprawnień ${ }^{4}$. Podobne stanowisko zostało wyrażone

${ }^{3}$ Obywatelom należącym do mniejszości zapewnia się możliwość wszechstronnego rozwoju, w tym m.in.: prawo do rozwijania własnej kultury, rozpowszechniania i otrzymywania informacji w języku macierzystym i tworzenia zrzeszeń narodowościowych, co szczegółowo reguluje ustawa (art. 25 ust. 1). Ponadto postanowienia Karty gwarantują członkom mniejszości prawo do pobierania nauki, używania własnego języka w stosunkach urzędowych oraz prawo do uczestnictwa w podejmowaniu decyzji dotyczących mniejszości narodowościowych i etnicznych (art. 25 ust. 2).

${ }^{4}$ Rekomendacja Komitetu Ministrów Rady Europy nr Rec(85) 13 dla państw członkowskich w sprawie instytucji Rzecznika Praw Obywatelskich, przyjęta przez Komitet Ministrów w dniu 
w zaleceniu z dnia 30 września 1997 roku, w sprawie ustanowienia niezależnych krajowych instytucji zajmujących się promowaniem i ochroną praw człowieka. Wezwano w nim do rozważenia ustanowienia instytucji ombudsmana lub instytucji o podobnym charakterze ${ }^{5}$ Taką potrzebę dostrzegano przede wszystkim w krajach dotkniętych nagłymi zmianami społecznymi i politycznymi, transformacją gospodarczą lub gwałtownymi wydarzeniami o charakterze wojennym prowadzącymi do zagrożeń dla ludzi, przemysłu, społeczeństwa i kultury prawa ${ }^{6}$. Duży wpływ miały również starania Republiki Czeskiej o przystąpienie do Unii Europejskiej, która skłaniała ku tworzeniu instytucjonalnych gwarancji ochrony praw człowieka (Cardenas 2014, 275). Unia Europejska stawiała wymóg utworzenia niezależnego organu właściwego do spraw równości wszystkim państwom, które chciały przystąpić do tej organizacji. Republika Czeska w tym zakresie traktowana była podobnie jak Bułgaria, Węgry, Łotwa, Rumunia i Słowacja. W Republice Czeskiej powołano zatem m.in. Rządową Komisję do Ochrony Praw Człowieka w 1998 roku $^{7}$ oraz ombudsmana, nazwanego publicznym obrońca praw, powołanego na mocy ustawy z dnia 8 listopada 1999 roku $^{8}$. Wejście w życie tej ustawy poprzedzały dość długie i intensywne prace nad szeregiem podobnych inicjatyw, które nie przyniosły jednak spodziewanych rezultatów (Skotnicki 2009, 659 i n.). Procedura powołania pierwszego publicznego obrońcy praw również w praktyce wywołała spore trudności, a kadencja pierwszego ombudsmana rozpoczęła się dopiero 18 grudnia 2000 roku (tamże, 661).

W pracach nad koncepcją instytucji ombudsmana inspirowano się rozwiązaniami obowiązującymi już w innych europejskich państwach, takich jak np. Wielka Brytania, Francja, Niemcy, Portugalia, Dania, Holandia, ale również Polska, w której rzecznik praw obywatelskich został powołany w 1988 roku?

23.09.1985 r. na 388. zebraniu Zastępców Ministrów; https://wcd.coe.int/ViewDoc.jsp?id=589191 [dostęp 23.01.2018].

${ }^{5}$ Rekomendacja Komitetu Ministrów Rady Europy nr Rec(97)14 E w sprawie tworzenia niezależnych krajowych instytucji promowania i ochrony praw człowiek, przyjęte przez Komitet Ministrów w dniu 30.09.1997 r. na 602. zebraniu Zastępców Ministrów; https://wcd.coe.int/ViewDoc. jsp?id=589191 [dostęp 23.01.2018].

${ }^{6}$ Zob. również: https://www.ochrance.cz/en [dostęp 23.01.2018].

${ }^{7}$ Rządowa Komisja do spraw Ochrony Praw Człowieka jest stałym organem doradczym rządu w dziedzinie ochrony praw człowieka i podstawowych wolności na terytorium Republiki Czeskiej. Została utworzona na podstawie uchwały rządu nr 809 z dnia 9.12.1998 r. Komisja ta monitoruje realizację postanowień Konstytucji Republiki Czeskiej oraz z Karty Praw Podstawowych w zakresie praw człowieka i podstawowych wolności oraz realizację na szczeblu międzynarodowym międzynarodowych zobowiązań Republiki Czeskiej w dziedzinie praw człowieka i podstawowych wolności; https://www.vlada.cz/government-council-for-human-rights-50632 [dostęp 23.01.2018].

${ }^{8}$ Ustawa nr 349/1999 o Publicznym Obrońcy Praw (Zákon o Veřejném ochránci práv), która weszła w życie 28.02.2000 r.

${ }^{9}$ Pierwszego rzecznika - prof. Ewę Łętowską powołał Sejm Polskiej Rzeczypospolitej Ludowej uchwałą z dnia 19.11.1987 r. (M. P. z 1987 r., nr 34, poz. 293). Zob. również: Skulová, Potěšil, Hejč (2014, 402); Klíma (2002, 403). 
Za niewątpliwą zaletę instytucji ombudsmana uznawano możliwość wszczęcia postępowania nawet w sytuacji, w której działanie organu lub innej instytucji publicznej jest zgodne $\mathrm{z}$ obowiązującym prawem, ale jednocześnie jest $\mathrm{w}$ inny sposób nieprawidłowe lub niesprawiedliwe. Ponadto zdawano sobie sprawę, że ombudsman może skutecznie wypełniać rolę mediatora między zaangażowanymi w spór stronami. Bazując na doświadczeniach państw europejskich, w których instytucja ta od dawna funkcjonowała podkreślano wielkie znaczenie ombudsmana jako organu, którego samo istnienie i potencjalna możliwość wszczęcia postępowania wpływały na świadomość działających w ramach organów i instytucji publicznych osób, które musiały się liczyć z potencjalną możliwością wszczęcia postępowania oceniającego ich pracę.

Doświadczenia obcych państw nie były jednak zawsze możliwe do przyjęcia w Republice Czeskiej, wyróżniającej się własnym systemem prawnym i swoistymi stosunkami wielonarodowego społeczeństwa, będącymi m.in. skutkiem aksamitnej rewolucji (Cardenas 2014, 275; zob. więcej Kruk 2009, 14-19). Chociaż w ustawie odwołano się do podstawowych, uznanych na szczeblu międzynarodowym zasad odnoszących się do organizacji i funkcjonowania instytucji ombudsmana, to jednak czeska regulacja zawiera rozwiązania oryginalne.

Pierwszy czeski ombudsman powołany został 12 grudnia 2000 roku przez parlament. Podstawowym problemem, z którym musiał się zmierzyć było zapewnienie należytej niezależności i profesjonalizmu prowadzonych postępowań. Jednak pomimo wielu trudności rola tej instytucji stale rośnie, a ombudsmanowi powierzane są coraz to nowe kompetencje. Chodzi tu między innymi o powierzenie mu od 2006 roku kompetencji w ramach krajowego mechanizmu prewencji, w rozumieniu Protokołu fakultatywnego do Konwencji w sprawie zakazu stosowania tortur oraz innego okrutnego, nieludzkiego lub poniżającego traktowania albo karania, przyjętego przez Zgromadzenie Ogólne Narodów Zjednoczonych w Nowym Jorku dnia 18 grudnia 2002 roku $^{10}$, od 2008 roku uprawnień związanych $\mathrm{z}$ administracją sądową, tj. prawo do wszczęcia postępowania dyscyplinarnego przeciwko prezesowi i wiceprezesowi sądu w razie naruszania przez nich obowiązków z zakresu administracji sądowej, od 2009 roku kompetencji związanych z realizacją zasady równouprawnienia oraz pomocy ofiarom dyskryminacji, a od 2011 roku obowiązku monitorowania przypadków zatrzymania cudzoziemców oraz wykonywania decyzji o ich wydaleniu z kraju.

Zadaniem Publicznego Obrońcy Praw jest rozpatrywanie skarg obywateli na niewłaściwe administrowanie (tzw. maladministrację; Gajda 2013, 26-28), zaniechanie lub niewłaściwe wykonywanie zadań przez organy administracji publicznej. Ombudsman chroni jednostki przed sprzecznymi z prawem lub niezgodnymi

${ }^{10}$ Konwencja w sprawie zakazu stosowania tortur oraz innego okrutnego, nieludzkiego lub poniżającego traktowania albo karania przyjęta przez Zgromadzenie Ogólne Narodów Zjednoczonych 10.12.1984. Zob. Rezolucja nr 39/46 z 10.12.1984 r. wraz z aneksem (UN Doc. A/RES/39/46 z 17.12.1984 r.); http://www.un.org/documents/ga/res/39/a39r046.htm [dostęp 23.01.2018]. 
ze standardami demokratycznego państwa prawa i dobrej administracji działaniami, a nawet bezczynnością instytucji i organów władzy publicznej wymienionych w ustawie, przyczyniając się w ten sposób do ochrony podstawowych praw i wolności jednostki.

Wśród organów, które podlegają kontroli ombudsmana w ustawie wymienione zostały ministerstwa oraz inne centralne organy państwowe i podlegające im urzędy sprawujące władzę publiczną, Czeski Bank Narodowy, w zakresie w jakim działa jako organ administracji publicznej, Radę do Spraw Radia i Telewizji, organy jednostek samorządu terytorialnego $\mathrm{w}$ zakresie wykonywania przez nie zadań z zakresu administracji państwowej oraz inne podmioty, takie jak czeska Policja, Siły Zbrojne, Straż Graniczna, Służba Więzienna, jak również wszystkie ich placówki wykonujące swe zadania względem osób pozbawionych wolności m.in. w aresztach, więzieniach, zakładach wychowawczych, opieki ochronnej lub instytucjonalnej, a także publiczne zakłady ubezpieczeń zdrowotnych. Ustawa w $\S 1$ ust. 5 wyraźnie wyłączyła spod kompetencji Publicznego Obrońcy Parlament, Prezydenta Republiki, rząd, Najwyższy Urząd Kontroli, służby informacyjne Republiki Czeskiej, organy wymiaru sprawiedliwości z zakresu postępowania karnego, prokuratury i sądów, z wyjątkiem organów wykonujących czynności administracyjne w prokuraturze i sądach.

3.

Publiczny Obrońca Praw wykonuje kompetencje w zakresie równego traktowania i ochrony przed dyskryminacją. Podobnie jak w Polsce, kompetencje $\mathrm{z}$ tego zakresu zostały ombudsmanowi powierzone w wykonaniu dyrektyw Unii Europejskiej ${ }^{11}$, w których podkreślano, że ochrona przed dyskryminacją zostałaby wzmocniona, gdyby w każdym państwie członkowskim istniał jeden lub kilka organów, których zadaniem byłoby analizowanie problemów związanych z dyskryminacją, badanie możliwych rozwiązań i świadczenie konkretnej pomocy ofiarom. Zgodnie bowiem z art. 13 dyrektywy 2000/43/WE państwa członkowskie zobowiązane zostały do wyznaczenia organu lub organów mających wspierać równe traktowanie wszystkich osób bez dyskryminacji ze względu na pochodzenie rasowe lub etniczne, które mogą wchodzić w skład organów zajmujących się

${ }^{11}$ Dyrektywa Rady 2000/43/WE z dnia 29.06.2000 r. wprowadzająca w życie zasadę równego traktowania osób bez względu na pochodzenie rasowe lub etniczne; dyrektywa Rady 2000/78/WE z dnia 27.11.2000 r. ustanawiająca ogólne warunki ramowe równego traktowania w zakresie zatrudnienia i pracy; dyrektywa 2004/113/WE z dnia 13.12.2004 r., wprowadzająca zakaz dyskryminacji z powodu płci w dostępie do dóbr i usług; dyrektywa 2006/54/WE z dnia 5.08.2006 r. w sprawie wprowadzenia w życie zasady równości szans oraz równego traktowania kobiet i mężczyzn w dziedzinie zatrudnienia i pracy; dyrektywa 2008/426/WE z dnia 2.07.2008 r. w sprawie wprowadzenia w życie zasady równego traktowania osób bez względu na religię lub światopogląd, niepełnosprawność, wiek lub orientację seksualną; http://eur-lex.europa.eu [dostęp 23.01.2018]. 
na skalę krajową obroną praw człowieka lub ochroną praw jednostek. Zgodnie z dyrektywą zadaniem tych organów powinno być świadczenie niezależnej pomocy ofiarom dyskryminacji we wnoszeniu skarg dotyczących dyskryminacji, prowadzenie niezależnych badań nad dyskryminacją oraz publikowanie niezależnych sprawozdań i wydawanie zaleceń na temat wszystkich problemów związanych z tego rodzaju dyskryminacją. Dyrektywa 2006/54/WE wprowadziła dodatkową kompetencję, którą mają wykonywać organy powołane do spraw równości, a mianowicie obowiązek wymiany dostępnych informacji z właściwymi organami europejskimi, takimi jak Europejski Instytut do spraw Równości Płci ${ }^{12}$.

Podstawowym warunkiem, według którego organ do spraw równości ma wykonywać powierzone mu zadania jest obowiązek zapewnienia mu niezależności. Wobec braku uregulowania tej kwestii w dyrektywach, w interpretacji tego wymogu często sięga się do tzw. zasad paryskich ${ }^{13}$, które w sposób szczegółowy określają aspekt niezależności funkcjonowania instytucji stojących na straży praw człowieka. Zawierają one m.in. wyjaśnienie i opis głównych obowiązków takiego organu, a także wspólne normy określające zasady ich funkcjonowania. Wskazują na standardy minimalne, które muszą być przestrzegane, by zapewniona była niezależność i bezstronność instytucji. Podkreślają m.in. konieczność zagwarantowania szerokiego mandatu do działania, niezależności od władzy wykonawczej, zagwarantowania adekwatnych środków i uprawnień do prowadzenia spraw. Podstawową cechą krajowych organów ma być zatem ich niezależność i bezstronność, uwzględniana zarówno w wymiarze instytucjonalnym i funkcjonalnym, jak i finansowym. Analizą aspektów niezależności organów ds. równego traktowania zajmuje się m.in. EQUINET - Europejska Sieć Urzędów ds. Równego Traktowania (Yesilkagit, Snijders 2008). Niezależność musi być zagwarantowana i realizowana na gruncie obowiązującego prawa wewnętrznego, ale również powinna być realizowana w praktyce działania takiego organu.

Patrząc z tej perspektywy należy zauważyć, że Publiczny Obrońca Praw Republiki Czeskiej spełnia określone w Zasadach Paryskich wymagania. Jest bowiem niezależnym i bezstronnym organem wybieranym przez Izbę Poselską Parlamentu na 6-letnią kadencję spośród czterech kandydatów, przedstawionych po dwóch przez prezydenta i przez Senat. Ta sama osoba może być wybrana jedynie na dwie kolejne kadencje. Publicznym obrońcą może zostać osoba, która ma bierne prawo wyborcze do Senatu, a więc oprócz obywatelstwa Republiki Czeskiej i czynnego prawa wyborczego musi mieć ukończony 40. rok życia, co stanowi gwarancję posiadania odpowiedniej do tego stanowiska wiedzy i doświadczenia życiowego. Ustawa dość szczegółowo określa w § 3 obowiązujący ombudsmana

${ }^{12}$ Rozporządzenie (WE) nr 1922/2006 Parlamentu Europejskiego i Rady z dnia 20 grudnia 2006 r. ustanawiające Europejski Instytut ds. Równości Kobiet i Mężczyzn (Dz.U. UE L 403/9 z 30.12.2006).

${ }^{13}$ Rezolucja Zgromadzenia Ogólnego ONZ z dnia 20 grudnia 1993 r., A/RES/48/134; http:// www.un.org/documents/ga/res/48/a48r134.htm [dostęp 23.01.2018]. 
zakaz łączenia stanowiska z urzędem Prezydenta Republiki, posła, senatora, sędziego, jak również z każdą inną działalnością w administracji publicznej. Nie może również prowadzić działalności zarobkowej, z wyjątkiem administrowania własnym majątkiem oraz wykonywanej we własnym imieniu działalności naukowej, pedagogicznej, publicystycznej, literackiej lub artystycznej, chyba że działań takich nie da się pogodzić z godnością urzędu lub podważają one zaufanie do jego niezależności lub bezstronności. Ombudsman nie może być członkiem partii politycznej ani ruchu politycznego. Podczas pełnienia funkcji publiczny obrońca nie podlega poborowi do wojska, jest zwolniony z obowiązku czynnej służby wojskowej lub jest ona przerywana, nie może być również powołany na ćwiczenia wojskowe. Jak zauważył K. Skotnicki, rozwiązanie to stanowi zabezpieczenie przed próbą wywierania nacisków na publicznego obrońcę, który w zakresie swojego działania zajmuje się również sprawami armii (Skotnicki 2009, 661).

W $\S 5$ ustawy wyrażona została expressis verbis zasada niezawisłego wykonywania funkcji przez Publicznego Obrońcę Praw, przy czym zgodnie z ust. 2 w związku z wykonywaną funkcją ponosi on odpowiedzialność przed Izbą Poselską. Odwołanie ombudsmana ze stanowiska może nastąpić jednak tylko w przypadku naruszenia zakazu niepołączalności lub zakazu przynależności do partii politycznej lub ruchu politycznego. Obrońca bowiem chroniony jest immunitetem. Zgodnie z § 7 ustawy ombudsmana nie można pociągnąć do odpowiedzialności karnej bez zgody Izby Poselskiej, której brak sprawia, że takie postępowanie będzie można wszcząć jedynie po zakończeniu jego kadencji (Skotnicki 2009, 662; Klima 2002, 404).

Niezależność Publicznego Obrońcy wzmacnia również rozwiązanie, zgodnie z którym zarówno wszczęcie postępowania, jak i sposób jego prowadzenia jest niezależną decyzją tego organu. Może on podejmować działania na skutek wniesionej przez osobę fizyczną lub prawną skargi lub z własnej inicjatywy. Ciekawym rozwiązaniem jest możliwość uruchomienia postępowania przed Publicznym Obrońcą w sposób pośredni, a więc za pośrednictwem parlamentarzysty lub nawet poprzez przekazanie mu przez jedną z izb parlamentu skargi skierowanej do którejś z nich. Publiczny Obrońca nie jest jednak traktowany jako organ administracyjny, któremu inne ograny państwowe mogą przekazać sprawę według właściwości.

W ustawie zwraca uwagę fakt, że uruchomienie postępowania skargą chociaż nie jest szczególnie skomplikowaną czynnością, to jednak wymaga spełnienia szczegółowo w ustawie wskazanych wymogów formalnych, a ich niespełnienie może skutkować odmową rozpatrzenia skargi. Ponadto musi być złożony w określonym terminie, a konkretnie w ciągu roku od uprawomocnienia się rozstrzygnięcia, postanowienia lub wydarzenia, które było przedmiotem skargi. Tym m.in. różni się to postępowanie od postepowania przed polskim Rzecznikiem Praw Obywatelskich, które wydaje się być dużo mniej sformalizowane. 


\section{4.}

Od 2009 roku zgodnie z art. 21b ustawy o Publicznym Obrońcy Praw, organ ten przyczynia się do promowania prawa do równego traktowania wszystkich osób bez względu na ich rasę, pochodzenie etniczne, narodowość, płeć, orientację seksualną, wiek, niepełnosprawność, religię, przekonania czy poglądy. W tym zakresie działa również w oparciu o postanowienia Karty Podstawowych Praw i Wolności oraz tzw. ustawy antydyskryminacyjnej ${ }^{14}$. Kryteriów, według których ocenia się przypadki dyskryminacji jest więcej i wynikają one $\mathrm{z}$ różnych ustaw. Wymienić wśród nich można kryterium własności, przynależności do związków zawodowych lub partii politycznych i ruchów politycznych, status rodzinny itp.

Aby skutecznie wykonywać zadania związane ze staniem na straży zasady równości i zakazu dyskryminacji w Biurze Publicznego Obrońcy Praw utworzono Departament do Spraw Równego Traktowania, w którym obecnie pracuje jedenaście osób. Biuro to wypełnia zadania związane z profesjonalnym, organizacyjnym i technicznym wsparciem działań ombudsmana. Ustawa przewiduje również, że Publiczny Obrońca może w drodze aktów wewnętrznie wiążących regulować wewnętrzną strukturę organizacyjną Biura, tak by jak najefektywniej realizować powierzone mu ustawą zadania. Publiczny Obrońca Praw określając swoją wizję działalności w ramach tej, nowej funkcji określił ją jako prowadzenie działalności opartej na trzech filarach: informowanie, edukacja i pomoc ${ }^{15}$.

Działalność informacyjna, stanowiąca pierwszy filar działalności Publicznego Obrońcy Praw skupia się przede wszystkim na wydawaniu zaleceń, opinii oraz prowadzeniu badań $\mathrm{w}$ zakresie równego traktowania. Jego zadaniem jest informowanie społeczeństwa o dostrzeżonych przypadkach nierównego traktowania, komentowanie zaistniałych przypadków dyskryminacji oraz wskazywanie sposobów unikania podobnych sytuacji w przyszłości. Głównym działaniem ombudsmana w tym obszarze jest informowanie o prowadzonych badaniach związanych z dyskryminacją, jak również podawanie do publicznej wiadomości wyników tych badań. Zarówno zalecenia, jak i opinie dotyczące prawa do równego traktowania i ochrony przed dyskryminacją wydawane przez Publicznego Obrońcę skupiają się na wskazaniu konkretnych przejawów dyskryminacji, a następnie na sformułowaniu zaleceń w zakresie możliwości odnalezienia sposobów dzięki którym uniknie się takich nieprawidłowości w przyszłości. Różnica między zaleceniami i opiniami sprowadza się do ich adresata. Zalecenia kierowane są do ogółu społeczeństwa, podczas gdy opinie przeznaczone są dla profesjonalistów. Zawierają one bardziej złożoną argumentację prawną, odniesienia do orzeczeń sądowych itp.

${ }^{14}$ Ustawa nr 198/2009 z dnia 23.04.2008 r. w sprawie równego traktowania i prawnych środków ochrony przed dyskryminacją i zmiany niektórych ustaw; https://www.ochrance.cz/fileadmin/ user_upload/DISKRIMINACE/pravni_predpisy/Anti-discrimination-Act.pdf [dostęp 23.01.2018].

${ }^{15} \mathrm{https}: / /$ www.ochrance.cz [dostęp 23.01.2018]. 
Publiczny Obrońca Praw, działając w ramach drugiego filaru, koncentruje się na realizacji projektów o charakterze edukacyjnym, w tym na organizowaniu seminariów tematycznych, warsztatów i szkoleń przeznaczonych dla organizacji non-profit, organów i urzędów administracji państwowej, pracodawców i usługodawców. Podejmuje również współpracę z wydziałami prawa uczelni wyższych.

Równie wielką wagę Publiczny Obrońca Praw przywiązuje do aktywności w ramach trzeciego filaru, a więc do pomocy ofiarom dyskryminacji. Ma ona dla ombudsmana kluczowe znaczenie. Każda osoba, która jest ofiarą dyskryminacji ma prawo nieodpłatnie zwrócić się do Publicznego Obrońcy, który po zapoznaniu się ze sprawą i rozpatrzeniu jej z prawnego punktu widzenia, stwierdza, czy dyskryminacja rzeczywiście miała miejsce, formułuje swoje uwagi i przedstawia sugestie dotyczące możliwego dalszego postępowania. Zapewnia również doradztwo lub współpracę w zakresie przygotowania dowodowego do dalszego postępowania w sprawie. W ten sposób realizuje art. $21 \mathrm{~b}$ lit. a ustawy. Publiczny Obrońca zapewnia pomoc ofiarom dyskryminacji przy składaniu wniosków o wszczęcie właściwego postępowania w sprawie dyskryminacji.

Ombudsman podejmuje współpracę $\mathrm{z}$ wieloma różnymi organizacjami, w tym np. od 2012 roku z organizacją pozarządową udzielającą pomocy pro bono - Pro Bono Aliance (PBA) ${ }^{16}$, przede wszystkim w zakresie świadczenia bezpłatnej pomocy prawnej dla skarżących. Na podstawie zawartego porozumienia PBA organizuje bezpłatną pomoc prawną ofiarom dyskryminacji, które chcą dochodzić swoich praw w postępowaniu sądowym, a które z powodu braku funduszy lub innych niekorzystnych warunków nie mogą sobie pozwolić na usługi prawne, gdy ombudsman stwierdził, że najprawdopodobniej doszło do dyskryminacji. Prawnicy pracujący w biurze Rzecznika Praw Obywatelskich udzielają również konsultacji z zakresu dyskryminacji prawnikom współpracującym w PBA. Od czasu podjęcia współpracy prawnicy z PBA podjęli się reprezentacji ofiar dyskryminacji w ponad dziesięciu przypadkach.

Publiczny Obrońca podejmuje również współpracę z Czeską Izbą Adwokacką (CAC), która poprzez wykonywaną działalność zapewnia odpowiednią jakość usług prawniczych. Zgodnie z art. 18 rezolucji z 31 stycznia 1997 roku $^{17}$ adwokaci w określonym zakresie mogą być zobowiązani do wzięcia udziału w projektach mających na celu promocję lub obronę praw i wolności człowieka lub mających na celu wdrożenie zasad demokratycznego państwa prawa czy poprawę porządku prawnego Republiki Czeskiej, nawet bez prawa do wynagrodzenia. Mogą być również angażowani w pomoc ofiarom dyskryminacji poprzez działalność w ramach organizacji świadczących bezpłatną pomoc prawną.

${ }^{16}$ www.probonoaliance.cz [dostęp 23.01.2018].

${ }^{17}$ Usnesení představenstva č. 1/1997 Věstníku, kterým se stanoví pravidla profesionální etiky a pravidla soutěže advokátů; https://www.cak.cz/scripts/detail.php?id=385 [dostęp 23.01.2018]. 
Niewątpliwie na skuteczność działania Publicznego Obrońcy Praw w zakresie realizacji zasady równości w istotny sposób wpływa przyznanie mu prawa tzw. inspiracji prawodawczej. Może bowiem wywierać wpływ na kształt obowiązujących przepisów prawnych poprzez możliwość wystąpienia do właściwego organu posiadającego kompetencje w zakresie prawodawstwa $\mathrm{z}$ wnioskiem o wystąpienie z inicjatywą ustawodawczą lub o wydanie, zmianę lub uchylenie przepisów obowiązujących w przestrzeni praw i wolności obywatelskich. Kolejnym środkiem przyznanym przez ustawę, a zapewniającym skuteczność działania Publicznego Obrońcy, jest możliwość wystąpienia z wnioskiem do Czeskiego Sądu Konstytucyjnego o zbadanie konstytucyjności przepisów prawa.

Ombudsman jako swój największy sukces przedstawia działalność w zakresie równego traktowania przez osoby niepełnosprawne, zwieńczony sporządzonym przez rząd projektem ustawy regulującej prawa osób niepełnosprawnych i korzystania $\mathrm{z}$ asysty wyszkolonych psów przewodników. Za inny sukces Publiczny Obrońca uznaje dokonane zmiany w zakresie sformułowania czytelnych kryteriów wpływających na równy dostęp do edukacji (zapisów do pierwszej klasy szkół podstawowych), przy czym podkreśla, że w czeskich szkołach wciąż aktualny jest problem segregacji dzieci romskich. Publiczny Obrońca przyznaje jednak, że nie we wszystkich działaniach udaje się ten sukces osiągnąć. Jako jeden z takich problemów, co do których nie udało się osiągnąć zamierzonych rezultatów, wskazuje na wciąż istniejące różnice w wynagrodzeniach kobiet i mężczyzn, zapowiadając kontynuowanie dyskusji w tej kwestii i przedstawienie określonych propozycji rozwiązań problemów w najbliższym czasie ${ }^{18}$.

Szczegółowych informacji o działalności Publicznego Obrońcy Praw Republiki Czeskiej dostarczają sporządzane corocznie pisemne sprawozdania z działalności, przedstawiane Izbie Poselskiej do 31 marca każdego roku za rok ubiegły. Obowiązek taki nakłada na niego $§ 23$ ustawy. Rzecznik przekazuje jednocześnie sprawozdanie Senatowi, prezydentowi Republiki, rządowi oraz ministerstwom $\mathrm{i}$ innym wskazanym ustawą organom administracyjnym. Rzecznik dokonuje publikacji tego sprawozdania. Ponadto Publiczny Obrońca Praw regularnie, nie rzadziej niż co trzy miesiące, informuje Izbę Poselską o działaniach Biura, a także przekazuje informacje o poszczególnych sprawach, które pomimo interwencji ombudsmana nie spotkały się z odpowiednią reakcją organów, do których działalności się odnosiły (§ 24). Dodatkowo systematycznie informuje opinię publiczną o swoich działaniach. Publikuje również raporty z przeprowadzonych interwencjach oraz wybrane sprawozdania z zakończonych postępowań.

${ }^{18}$ Roczne sprawozdanie Publicznego Obrońcy Praw za 2016 r. dostępne na stronie: https:// www.ochrance.cz [dostęp 23.01.2018]. 
Publiczny Obrońca Praw Republiki Czeskiej spełnia ustrojowe wymagania, które stawiane są przez dyrektywy unijne organom do spraw równości. Według badań przeprowadzonych przez Komisję Europejską utworzone w państwach członkowskich organy tego typu zajmują się przede wszystkim promowaniem dobrych praktyk w zakresie równości, podnoszeniem świadomości w zakresie tematu równości i niedyskryminacji oraz zapewnianiu porad prawnych i pomocy indywidualnym ofiarom dyskryminacji. Przez ponad siedem lat stania na straży zasady równości i przeciwdziałania dyskryminacji Publiczny Obrońca Praw Republiki Czeskiej dostrzegł znaczny wzrost liczby skarg dotyczących tego problemu. W 2010 roku było ich 178 w roku 2016 - 451. Oprócz działań w sprawach indywidualnych w 2016 roku Publiczny Obrońca w 33 przypadkach zdecydował się na współpracę z międzynarodowymi instytucjami, odpowiedział na 24 zapytania publiczne, podjął w 15 przypadkach współpracę z organami rządowymi, a $\mathrm{w} 11 \mathrm{z}$ organizacjami pozarządowymi i prywatnymi oraz prowadził niezależne badania z zakresu dyskryminacji. Obrońca zauważył, że w jednej na dziesięć składanych skarg zarzut dyskryminacji był uzasadniony ${ }^{19}$.

Działalność Publicznego Obrońcy Praw stanowi okazję do dyskusji publicznej na temat zaistniałych problemów. Ombudsman bowiem prowadząc działalność we wskazanych powyżej formach dostarcza społeczeństwu koniecznej wiedzy, identyfikuje problemy oraz ich skalę, słucha, dyskutuje, odpowiada na pytania, przedstawia opcje i strategie rozwiązania problemów. Publiczny Obrońca Praw podkreśla, że w dobrze poinformowanym, wyedukowanym społeczeństwie dyskryminacja występuje stosunkowo rzadko. Stąd za swoją misję uważa niesienie skutecznej pomocy w zakresie równego traktowania i włączenia tematu dyskryminacji w ogólnospołeczną dyskusję. Wykorzystuje coraz to nowe formy dotarcia do jak najszerszego kręgu odbiorców, takich jak media, Internet, portale społecznościowe. Podejmowane przez siebie działania ocenia jako sukces ${ }^{20}$.

\section{BIBLIOGRAFIA}

Cardenas, Sonia. 2014. Chains of Justice: The Global Rise of State Institutions for Human Rights. Philadelphia: University of Pennsylvania Press.

Gajda, Agnieszka. 2013. Kierunki rozwoju instytucji Rzecznika Praw Obywatelskich w Polsce. Warszawa: Wydawnictwo Sejmowe.

Klíma, Karel. 2002. Ústavní právo. Dobrá voda u Pelhřinova: Vydatelství a nakladatelství Aleš Čěnek.

Kruk, Maria. 2009. Wstęp. W Konstytucja Republiki Czeskiej. Warszawa: Wydawnictwo Sejmowe. Skotnicki, Krzysztof. 2000. System konstytucyjny Czech. Warszawa: Wydawnictwo Sejmowe.

\footnotetext{
${ }^{19}$ Tamże.

${ }^{20}$ Tamże.
} 
Skotnicki, Krzysztof. 2009. Publiczny Obrońca Praw Człowieka Republiki Czeskiej. W Instytucje prawa konstytucyjnego $w$ dobie integracji europejskiej. Księga jubileuszowa dedykowana Prof. Marii Kruk-Jarosz. Red. Jan Wawrzyniak, Marzena Laskowska. Warszawa: Wydawnictwo Sejmowe.

Skulová, Soňa, Potěšil Lukáš, Hejč David. 2014. Administrative Appeals, Ombudsman, and Other ADR Tools in the Czech Administrative Law. W Alternative Dispute Resolution in European Law. Eds. Dacian Dragos, Bogdana Neamtu. Berlin-Heidelberg: Springer Verlag.

Yesilkagit, Kutsal, Berend Snijders. 2008. Between Impartiality and Responsiveness Equality Bodies and Practices of Independence. Report. University of Utrecht Commissioned by Equinet (http:// www.equineteurope.org/IMG/pdf/EN___Between_Impartiality_and_Responsiveness.pdf).

\section{Akty prawne}

Ustawa konstytucyjna nr 1/1993 Sb. (Karta Podstawowych Praw i Wolności).

Ustawa nr 349/1999 Sb.

Ustawa nr 198/2009 Sb.

Dyrektywa Rady 2000/43/WE z dnia 29.06.2000 roku wprowadzająca w życie zasadę równego traktowania osób bez względu na pochodzenie rasowe lub etniczne. http://eur-lex.europa.eu.

Dyrektywa Rady 2000/78/WE z dnia 27.11.2000 roku ustanawiająca ogólne warunki ramowe równego traktowania w zakresie zatrudnienia i pracy. http://eur-lex.europa.eu.

Dyrektywa Rady 2004/113/WE z dnia 13.12.2004 roku wprowadzająca zakaz dyskryminacji z powodu płci w dostępie do dóbr i usług. http://eur-lex.europa.eu.

Dyrektywa Rady 2006/54/WE z dnia 5.08.2006 roku w sprawie wprowadzenia w życie zasady równości szans oraz równego traktowania kobiet i mężczyzn w dziedzinie zatrudnienia i pracy. http://eur-lex.europa.eu.

Dyrektywa Rady 2008/426/WE z dnia 2.07.2008 roku w sprawie wprowadzenia w życie zasady równego traktowania osób bez względu na religię lub światopogląd, niepełnosprawność, wiek lub orientację seksualną. http://eur-lex.europa.eu.

Rekomendacja Komitetu Ministrów Rady Europy nr Rec (85)13 dla państw członkowskich w sprawie instytucji Rzecznika Praw Obywatelskich, przyjęta przez Komitet Ministrów w dniu 23.09.1985 r. na 388. zebraniu Zastępców Ministrów; https://wcd.coe.int/ViewDoc. jsp?id=589191.

Rekomendacja Komitetu Ministrów Rady Europy nr Rec (97)14E w sprawie tworzenia niezależnych krajowych instytucji promowania i ochrony praw człowiek, przyjęte przez Komitet Ministrów w dniu 30.09.1997 r. na 602. zebraniu Zastępców Ministrów; https://wcd.coe.int/ ViewDoc.jsp?id=589191.

Rezolucja Zgromadzenia Ogólnego ONZ z dnia 20.12.1993 roku; A/RES/48/134; http://www. un.org/documents/ga/res/48/a48r134.htm

Rozporządzenie (WE) nr 1922/2006 Parlamentu Europejskiego i Rady z dnia 20.12.2006 roku ustanawiające Europejski Instytut ds. Równości Kobiet i Mężczyzn (Dz.U. UE L 403/9 z 30.12.2006 r.). 
Agnieszka Gajda

\section{THE PUBLIC DEFENDER OF RIGHTS IN THE CZECH REPUBLIC AS A NATIONAL EQUALITY AUTHORITY IN THE CONTEXT OF STANDARDS SET BY DIRECTIVES OF THE EUROPEAN UNION}

\footnotetext{
Abstract. The subject of this study is evaluation of activities of the Public Defender of the Czech Republic in a scope of carrying out activities entrusted to him from 2009 as a national equality authority. It is intended to contribute to the promotion of the right to equal treatment of all persons irrespective of their race, ethnic origin, nationality, gender, sexual orientation, age, disability, religion, beliefs or views. In this respect, it also acts under provisions of the Constitution of the Czech Republic, the Charter of Fundamental Rights and Freedoms, the so-called anti-discrimination law and many other statutory regulations. These tasks were entrusted to the ombudsman in the process of implementation of EU directives. EU regulator emphasized that one of the ways to strengthen protection against discrimination in EU Member States is to establish bodies in order to analyze problems related to discrimination, examine possible solutions and provide specific assistance to victims. The author of this study deliberate whether the Public Defender of Rights meets requirements for national equality bodies, recalling the criteria set out in so-called The Paris Principles, which define in details the aspect of the independence of the functioning of institutions that safeguard human rights. In addition, author presents the basic assumptions on which the activity of the ombudsman is based, as well as description of the practice, and its activities in the area of ensuring implementation of the principle of equality.

Keywords: Public Defender of Rights of Czech Republic, national authority for equality, Constitution of the Czech Republic, Charter of Fundamental Rights and Freedoms, principle of equality, prohibition of discrimination
} 